Kinga Krzemińska

\title{
Kicz w kinie holokaustowym
}

\section{Z czym historyk musi się pogodzić przed pójściem do kina}

Na wstępie trzeba zaznaczyć kilka rzeczy. Po pierwsze, mówiąc o kiczu w filmach fabularnych dotyczących Zagłady, nie poruszamy się po gruncie historycznym i nie miejsce tu na analizowanie historycznego wydarzenia, jakim było wymordowanie Żydów w czasie II wojny światowej. W kulturze popularnej historia jest jedynie inspiracją, punktem wyjścia dla opowieści. To opowieść, przeznaczona dla szerokiej publiczności, a nie dla wąskiego grona znawców tematu, jest celem nadrzędnym. Filmy o Zagładzie nie są robione przez historyków, tylko przez ludzi pracujących w przemyśle filmowym - i o tym nie można zapominać. Nie pamiętając o tym, w zderzeniu z kinem holokaustowym nie uniknie się dogłębnej frustracji. Dlaczego? Ponieważ filmy dotyczące już nie tylko tematu Holokaustu, ale w ogóle II wojny światowej, a zapewne wręcz każdej wojny, są zawsze nieprawdziwe, w sensie niezgodności z datami, faktami, nazwiskami, dokumentami i świadectwami. Warto jednak pamiętać, że film fabularny nigdy nie był, nie jest i nie będzie świadectwem historycznym. Oczywiście nie twierdzę, że o tych przekłamaniach należy w ogóle zapomnieć czy je zignorować. Nie. Są one bardzo istotnym elementem rozważań dotyczących kiczu w kinematografii poświęconej Holokaustowi, czy też w jakimkolwiek stopniu dotykającej tej tematyki. Istnieje jednak niebezpieczeństwo, że jeśli skoncentrujemy się na przekłamaniach, niedociągnięciach, nieprawdziwościach natury stricte historycznej, możemy przeoczyć to, czego kino popularne świadectwem rzeczywiście jest, to, co faktycznie pokazuje i co może uświadomić, także jeśli chodzi o temat Zagłady i jego społecznej percepcji.

Tak więc znawca tematu musi się pogodzić z tym, że fakt historyczny będzie zawsze $\mathrm{w}$ filmie popularnym podrzędny wobec dramatycznej historii, przeciwności, które protagonista musi pokonać, będą zawsze nadrzędne wobec prawdopodobieństwa historycznego, a kulminacja fabuły na ekranie będzie stała na pierwszym miejscu, daleko przed potwierdzonymi źródłami i materiałami historycznymi. Tak przygotowany naukowiec może rozpocząć wędrówkę po kinie holokaustowym i spojrzeć na nie z zupełnie nowej perspektywy. Trzeba tylko najpierw sprecyzować i jasno określić, co oznacza termin „kino holokaustowe”. 


\section{Kino holokaustowe, czyli co?}

Jeżeli lata pięćdziesiąte ubiegłego wieku uważane są za złoty okres kina hollywoodzkiego, to lata dziewięćdziesiąte uważa się za okres rozkwitu kina dotyczącego tematyki Zagłady. Dla opinii publicznej momentem wejścia w pole widzenia tematu zbrodni nazistowskich wobec Żydów był proces Eichmanna w 1961 r. Dla kinematografii, czy szerzej przemysłu telewizyjno-filmowego, odpowiednikiem procesu Eichmanna stał się trwający dziewięć i pół godziny miniserial Holocaust wyprodukowany przez stację NBC w 1978 r. i emitowany w amerykańskiej telewizji przez cztery wieczory z rzędu.

Peter Novick, badacz zajmujący się mechanizmami kreującymi nową tożsamość diaspory amerykańskiej, a także tym, jak Holokaust wkroczył „na salony” kina i telewizji w Stanach Zjednoczonych, zaznacza wagę roli, którą serial odegrał w upublicznieniu tematu Zagłady: „w ciągu tych czterech wieczorów więcej informacji dotyczących Holokaustu dotarło do większej liczby Amerykanów niż przez ostatnie trzydzieści lat. Historia dotyczyła dwóch fikcyjnych rodzin: zasymilowanych Żydów niemieckich i rodziny wysoko postawionego urzędnika SS [...] serialowi udało się przedstawić najważniejsze punkty: ustawy norymberskie, "noc kryształową", konferencję w Wiedniu, Babi Jar, powstanie w getcie warszawskim, Buchenwald, Terezin i Auschwitz. Miniserial okazał się minikursem - przeglądem”1.

Historycy cały czas toczą dyskusję, od którego momentu można mówić o początku Zagłady. Czy było to podjęcie decyzji o ostatecznym rozwiązaniu kwestii żydowskiej, czy może moment stworzenia gett, czy też fakt sporządzenia list ludności żydowskiej? Kino popularne nie może sobie pozwolić na tak subtelne rozważania (dlaczego - mam nadzieję wyjaśnić później). Sposób, w jaki Novick wypunktował jako najważniejsze - elementy historii, które udało się zamieścić w serialu, może posłużyć jako pomoc przy stworzeniu opisu pewnego gatunku kina, który nazwę kinem holokaustowym.

W magazynach poświęconych kinu filmy te najczęściej określane są mianem dramatu wojennego. Łączy je szereg przeplatających się sukcesywnie elementów, których wymienienie może posłużyć jako sposób na zdefiniowanie filmu holokaustowego. Takimi elementami będą: obóz, życie/przeżycie w getcie, ukrywanie się (jeśli protagonista jest Żydem lub ukrywającym), transporty, głód, bestialstwo Niemców (czytaj: sadystyczne znęcanie się nad ludźmi), samoorganizowanie się Żydów w jednym w powyżej wymienionych miejsc, samoobrona Żydów (powstanie, partyzantka), sekwencja dokumentalna pod koniec filmu pokazująca pierwowzory bohaterów - ocalonych.

Każdy film, którego istotnym elementem fabuły jest którykolwiek z wyżej wymienionych elementów (istotnym to znaczy takim, który przymusza bohatera do działania albo jest kołem napędowym dla akcji filmu), zaliczę do kina holokaustowego. Tak więc czeski film Musimy sobie pomagać z 2000 r. w reżyserii Jana Hřebej-

${ }^{1}$ P. Novick, The Holocaust and collective memory, London 2001, s. 209. 
ka o ukrywaniu żydowskich sąsiadów i Szara strefa Tima Blake’a Nelsona z 2001 r., gdzie akcja toczy się wokół powstania zorganizowanego przez Sonderkommando w krematorium Auschwitz w 1944 r., zaliczę do filmów holokaustowych, podobnie jak filmy dziejące się w gettach, jak Jakub Kłamca z 1999 r. Petera Kassowitza czy Korczak Andrzeja Wajdy z 1990 r., czy też filmy bajkowe jak Życie jest piękne Roberta Benigniego z 1997 r. oraz Pociag życia Radu Mihăileanu z 1998. Bez względu na styl filmu i jego estetykę (która i tak najczęściej obfituje w kicz, o czym później), wszystkie te produkcje łączy jedno: „Niczym wspaniała baśń, filmy te są raczej symboliczne niż dosłowne, pozwalają naszej wyobraźni na skonfrontowanie się zarówno z mrocznymi siłami, jak i z uczuciem miłości”2.

Filmy dotykające tematu Zagłady posiadają zazwyczaj pewne powtarzające się elementy konstrukcji dramaturgicznych, które sprowadzają się do dwojakiego typu:

1) Ktoś ukrywa, ratuje czy wspomaga Żydów, a pytanie, które niesie fabułę, brzmi: czy uda mu się przechytrzyć Niemców i Żyd/Żydzi zostaną uratowani? Wariacją tego typu fabuły będzie przesunięcie w obrębie protagonisty, kiedy to Żydzi sami się ukrywają. Pytanie jednak pozostaje cały czas to samo.

2) Protagonista pochodzenia żydowskiego (może być protagonista grupowy) jest uwięziony w getcie, obozie i stara się wydostać na wolność. Pytanie, na którym opiera się konstrukcja dramaturgiczna w takim przypadku, będzie brzmiało: czy uda się im/mu/jej uciec z miejsca uwięzienia? Trzonem obu pytań jest ta sama kwestia: czy uda się przeżyć? I czy będzie to Pianista Romana Polańskiego z 2002 r., czy dużo starsza Ucieczka z Sobiboru Jacka Golda (1987), czy Dzieci Ireny Sendlerowej Johna Kenta Harrisona z 2009 - pytanie zawsze jest to samo: czy główny bohater przeżyje i jak tego dokona?

Filmem na granicy gatunku będą zeszłoroczne Bękarty wojny Quentina Tarantino, które fabularnie może nie powinny być brane pod uwagę jako kino holokaustowe, ale ze względu na jeden z wątków filmu (francuska Żydówka postanawia dokonać „żydowskiej zemsty”, podpalając swoje kino podczas premiery pełnej nazistowskich dygnitarzy), a także ze względu na estetykę i wymowę symboliczną, są tak fascynującym przykładem wykorzystania kiczu w kinie, że nieprzeanalizowanie go byłoby szkodą dla tematu.

Bękarty wojny świadomie wykorzystują estetykę kiczu, jednak znakomita część filmów o Holokauście zawiera w sobie elementy kiczu zastosowane całkowicie nieświadomie. Sądzę, że nawet nie znając wszystkich recenzji filmowych, można zaryzykować stwierdzenie, że każdy film holokaustowy był oskarżany o kiczowatość, banalizację historii czy też robienie z największej tragedii XX w. popkulturowej papki. Zarzuty, jakie krytycy kierują pod adresem tego typu filmów, są zazwyczaj podobne i opierają się na jednym fundamentalnym założeniu, a mianowicie, że kicz, upraszczanie czy dostosowywanie historii Zagłady do potrzeb kina popularnego są po prostu złe.

${ }^{2}$ A. Insdorf, Indelible Shadows: Film and the Holocaust, Cambridge 2003, s. 292. 


\section{Kicz jako zło}

Hermann Broch w roku 1936 napisał klasyczny dziś tekst Kilka uwag na temat kiczu. Zdefiniował w nim zjawisko kiczu jako kłamstwo, które polega na przesunięciu celu wykonania dzieła z poszukiwania prawdy, interpretacji świata, na wrażenia czysto estetyczne ${ }^{3}$. Piękno, które było środkiem służącym do poszukiwania nowego spojrzenia na rzeczywistość i odkrywania prawdy o świecie oraz człowieku, w przypadku kiczu staje się celem samym w sobie. Według Brocha korzenie kiczu tkwią w kulturze romantycznej, która była pierwszą epoką pozbawioną rzemiosła. Z twórczego geniuszu można było ześlizgnąć się jedynie w kicz. „Romantyzm - pisze Broch - chce uczynić platońską ideę sztuki, czyli Piękno, bezpośrednim, uchwytnym celem każdego dzieła sztuki”4.

Niezwykle krytyczne podejście do kiczu zapoczątkowane przez Brocha podtrzymywało wielu znawców sztuki. Jednym z nich był Clement Greenberg, amerykański krytyk sztuki, który w swoim, także klasycznym dziś tekście Awangarda i kicz pisał: „kicz to pokazanie skutku, gotowej recepty, sztuka to szukanie prawdy” ${ }^{\text {. Dla }}$ Greenberga najważniejszą cechą kiczu jest jego wtórność, powtarzalność. Cecha ta jest jego zdaniem nieuchronna, ponieważ genezy kiczu doszukuje się w rewolucji przemysłowej.

Nie sposób nie zauważyć, że filmy holokaustowe oferują gotowe recepty na rozumienie i interpretowanie Holokaustu. Ich - najczęściej szczęśliwe - zakończenia pozwalają widzowi na „rozumienie”, czy lepiej: potraktowanie Holokaustu jako lekcji tolerancji, testu na ludzką dobroć czy, bardziej banalnie, przeszkody, która na ekranie została pokonana przez protagonistę, a w rzeczywistości została pokonana przez ludzkość. Owe różne typy kiczowych sposobów na interpretowanie Holokaustu przeanalizuję później, tworząc minitypologię najczęściej obecnych kiczów holokaustowych w kinie.

Idąc tropem Greenberga, Maria Poprzęcka zdefiniowała kicz jako zjawisko dotyczące kultury bogatych społeczeństw postindustrialnych, społeczeństw obfitości. Poprzęcka zauważa także, że kiczowi zawsze przypisuje się negatywne walory estetyczne. Jednocześnie kicz, zarówno u Poprzęckiej, jak i u Greenberga, a zwłaszcza u Brocha, jest czymś więcej niż jedynie estetyką, podejściem do formy. Kicz jest sposobem myślenia, stanem umysłu, w którym znalazło się społeczeństwo akceptujące i przyzwalające na produkty tego typu. Broch analizuje kicz w kategoriach nie tyle czysto estetycznych, ile etycznych. „W jaki rodzaj dzieła kicz stara się przekształcić życie ludzkie? - pyta. - Odpowiedź jest prosta: w neurotyczny, to znaczy taki, który narzuca rzeczywistości konwencję całkowicie nierealną"6.

${ }^{3}$ H. Broch, Kilka uwag na temat kiczu i inne eseje, przeł. D. Borkowska, J. Garewicz, R. Turczyn, Warszawa 1998, s. 114.

${ }^{4}$ Ibidem, s. 114.

${ }^{5}$ C. Greenberg, Awangarda i kicz [w:] Kultura masowa, red. Cz. Miłosz, Paryż 1959, s. 41.

${ }^{6} \mathrm{H}$. Broch, op. cit., s. 116. 
Nietrudno odnieść powyższe rozważania na temat kiczu do filmów holokaustowych. Powtarzalność elementów tworzących tego typu obrazy jest niemożliwa do przeoczenia. Nie ma też wątpliwości co do tego, że wszystkie te filmy godzą w prawdziwość historyczną przedstawionych zdarzeń. Nie chodzi tu nawet o daty czy mieszanie faktów, a bardziej o nieprawdopodobieństwo historii, która zazwyczaj jest podstawą fabularną filmu. Wystarczy podać przykład Ucieczki z Sobibo$r u$, gdzie więźniowie po pracy spędzają czas w rodzaju świetlicy, śpiewając, grając w szachy i obmyślając plan ucieczki, czy też dużo nowszy film Chłopiec w pasiastej piżamie w reżyserii Marka Hermana ${ }^{7}$ z 2008 r., w którym żydowski chłopiec niezauważony przez nikogo siada w godzinach pracy pod płotem obozu i spędza tam cały dzień z pustą taczką zostawioną z boku.

Zabiegi dramaturgiczne tego typu służą wykreowaniu opowieści mieszczącej się w konkretnym gatunku znanym widzowi (dramat, tragedia), nie zaś dążeniu do przekazania jakiejkolwiek prawdy historycznej czy wytłumaczenia mechanizmów rządzących Zagładą. Tu właśnie tkwić będzie owo neurotyczne, według Brocha, czyli nierealne, całkowicie kiczowe przedstawienie Zagłady. Niewątpliwie można takie zabiegi nazwać kłamstwem, jeśli przyjmie się założenie, że opowieść jest podrzędna wobec prawdopodobieństwa historycznego, co wcale nie musi być założeniem oczywistym. Jednak nawet jeśli nie będziemy analizować filmów holokaustowych w kategoriach przekłamywania faktów, to kicz tego typu filmów będzie leżeć w chwytach dramaturgicznych nastawionych jedynie na podbicie emocji widza.

Najlepszym wyjaśnieniem tego, co takie traktowanie kiczu oznacza, jest w mikroskali scena z Listy Schindlera Stevena Spielberga z 1993 r., kiedy na Żydówki Schindlera, wepchnięte do komory gazowej, zamiast cyklonu B spływa woda. Jest to emocjonalna kulminacja filmu, bo jeśli Schindlerowi udało się zamienić cyklon B w wodę, to nie ma dla niego rzeczy niemożliwych. Mimo całego horroru tej i jej podobnych scen (cud ostatniej chwili), mamy poczucie, że twórcy filmów, nie bacząc na ciężar tematu, grają z nami w grę, której zasady doskonale znamy. Co więcej, nikt nas nie zaskakuje złamaniem tych zasad. Kicz, ze swoim nieskończonym powielaniem schematów przypomina kierunkowskaz na drodze, dzięki któremu wiemy, gdzie jesteśmy i dokąd mamy jechać. Daje poczucie bezpieczeństwa, że się nie zgubilismy.

Zarówno Broch, Greenberg, jak i Poprzęcka, przedstawiają podejście nie tyle krytyczne, ile negatywne w stosunku do kiczu. Podczas gdy ich zarzuty pod adresem kiczu - że jest on powtarzalny, kłamliwy, prymitywny - są w pełni uzasadnione, negatywne podejście do kiczu bagatelizuje całkowicie potencjał tkwiący w estetyce szczęścia, jak nazwał kicz Abraham Moles. A przecież to, że ktoś jest garbaty, wcale nie oznacza, że nie może mieć pięknych oczu.

${ }^{7}$ Sam film powstał na podstawie książki o tym samym tytule autorstwa Johna Boyne’a. Warto też wspomnieć, że Mark Herman jest twórcą takich komedii jak Orkiestra z 1997 r. czy O maty głos z 1998. 


\section{Esperanto kiczu}

Kultura masowa nie istnieje bez kiczu. Każdy przekaz zaadresowany do masy społecznej potrzebuje języka uniwersalnego, zrozumiałego i przystępnego. Kicz wszystko to oferuje. Abraham Moles, pisząc o funkcji pedagogicznej kiczu, o jego potencjale kreowania dobrego gustu poprzez zły gust, określił stosunek między kiczem a sztuką jako szczególnie wieloznaczny: „podobnie jak stosunki między społeczeństwem masowym a społeczeństwem twórczym. Kicz jest bowiem zasadniczo estetycznym systemem komunikacji masowej"8.

Jeżeli więc jedną z największych obaw badaczy Holokaustu jest możliwość, że zostanie on zapomniany, czyż jest lepszy sposób na oddalenie tego zagrożenia niż opowiadanie o Zagładzie językiem kiczu właśnie? Jeżeli ma się liczyć ilość ludzi, dla których Holokaust w ogóle zaistnieje jako fakt społeczny, nie jakość filozoficznej refleksji czy adekwatność historyczna, to wydaje się, że filmy popularne wyprodukowane w znacznej części w Stanach Zjednoczonych są najlepszym rozwiązaniem. Nie ma w kulturze masowej, przynajmniej na razie, niczego silniejszego niż filmowa superprodukcja. Na tym jednak nie kończy się potencjał, jaki niesie w sobie kicz, a w szczególności kicz filmów holokaustowych.

Krzysztof Piątkowski, pisząc o kulturze masowej w książce Kiczosfery wspótczesności, zauważa: „W Ameryce taka forma kultury powstaje od razu jako swoiste symboliczne esperanto, służąc porozumieniu między przedstawicielami różnych kultur, gdzie umasowienie przybierało charakter wyzwalającego otwarcia na wymiar uniwersalny, a nie lokalny"9.

Przypomnijmy Brocha i jego konstatację, że kicz to przede wszystkim estetyka nastawiona na programowanie emocji, które dzieło ma wzbudzać u odbiorcy. Filmy holokaustowe niewątpliwie są tego przykładem. Nie dają cienia swobody emocjonalnego odbioru, widz jest przymuszony wszelkimi możliwymi środkami filmowymi, takimi jak podbijanie napięcia montażem, kadrowaniem czy muzyką, do odczuwania pewnych konkretnych emocji. Kicz tych filmów umożliwia wpisanie pewnego wydarzenia, doświadczenia konkretnej grupy w świadomość mas. Dzieje się to nie tylko na poziomie racjonalnym, czyli na płaszczyźnie informacji, że Zagłada miała miejsce, ale również, jeśli nie głównie, na poziomie emocjonalnym, na poziomie odczuwania empatii wobec bohaterów, którzy zazwyczaj w kinie holokaustowym są Żydami.

Wydaje się, że dzięki sile oddziaływania i uniwersalizmowi kicz tych filmów (choć nie tylko filmy można by tu wymieniać, ale też scenariusze uroczystości upamiętniania ofiar, muzea, literaturę) dał możliwość przekształcenia doświadczenia lokalnego (w znaczeniu: dziejącego się w konkretnym miejscu i czasie przy zaanga-

${ }^{8}$ A. Moles, Kicz czyli sztuka szczęścia, przeł. A. Szczepańska, E. Wende, Warszawa 1978, s. 83.

${ }^{9}$ K. Piątkowski, Kicz jako problem antropologiczny [w:] Kiczosfery wspótczesności, red. W.J. Burszta, E.A. Sekuła, Warszawa 2008, s. 17. 
żowaniu konkretnej, skończonej liczby ludzi) w doświadczenie uniwersalne w sensie poznania go przez społeczeństwo masowe. Holokaust został przyjęty, wchłonięty przez masową świadomość. Trudno wskazać inne narzędzie poza kiczem, które mogło tego dokonać. Oczywiście, jest to Holokaust w krzywym zwierciadle, gdzie psy mają kagańce, ludzie wysiadają z wagonów bydlęcych w czystych koszulach, a w komorach gazowych mówią „proszę” i „dziękuję”, niemniej jednak jest to Holokaust straszny, mroczny i niebezpieczny. Jest to także obraz Holokaustu, który nieustająco pobudza do dyskusji, zmusza do konfrontacji, skłania do krytyki.

Wracamy tu do specyficznie rozumianej funkcji pedagogicznej kiczu, o której pisał Moles. W przypadku kiczu kina holokaustowego ta funkcja pedagogiczna może zostać rozszerzona także o inspirację i prowokację. Gdyby nie filmy takie jak Lista Schindlera, Życie jest piękne czy serial Holokaust, nie odbyłyby się ważne debaty na temat reprezentacji Zagłady, uprawnień twórców, mechanizmów upraszczania historii. A przecież są to tematy istotne nie tylko dla konkretnego tematu Zagłady, ale i w ogóle dla stanu kultury, w której żyjemy. Kicz, poza emocjami zaprogramowanymi w swoim przekazie, wzbudza kontrowersje, czyli w największym skrócie pobudza do reakcji, a co za tym idzie - do debaty publicznej. Dyskusja, która rozpoczyna się na nowo za każdym razem, gdy do kin wchodzi kolejny film holokaustowy, przyczynia się do poszerzenia świadomości społecznej na ten temat, a także do nowego interpretowania w kategoriach percepcji społecznej samego wydarzenia, którym było wymordowanie Żydów w czasie II wojny światowej.

Klisze ugruntowane poprzez kiczowe opowiadanie o Holokauście dają bazę wizualną dla dzieł sztuki wysokiej, starających się dotknąć mechanizmów kierujących Zagładą i ludzi, którzy ją przygotowali. Wykorzystują one obrazy i skojarzenia wygenerowane i utrwalane raz po raz przez to, co kiczowe. Lego. Obóz koncentracyjny Zbigniewa Libery nie byłoby możliwe bez zdjęć Auschwitz wykorzystywanych na lewo i prawo, bez skojarzeń utrwalonych przez filmy holokaustowe pierwszej połowy lat dziewięćdziesiątych. Kicz bowiem, powtarzając, utrwala i kreuje stereotypy. Kreuje pewne schematy asocjacyjne, które moga posłużyć jako budulec dla sztuki ambitnej. Bez uniwersalnego języka kiczu nie byłoby czego przełamywać, z czym polemizować.

Bez wykorzystania kiczu proces przekształcenia Zagłady z konkretnego wydarzenia w uniwersalną przypowieść, swego rodzaju mit współczesności nie byłby możliwy. Inną kwestią pozostaje, że Zagłada w tej uniwersalnej wersji przemienia się w opowieść baśniową, całkowicie zewnętrzną wobec dzisiejszego, ponowoczesnego społeczeństwa. Ceną, jaką płacimy za opowiadanie Holokaustu jako doświadczenia masowo poznawalnego i możliwego do pojęcia, jest stworzenie obrazów na miarę codzienności, po których obejrzeniu można o własnych siłach wyjść z kina, wrócić do domu i spokojnie zjeść obiad. 


\section{Holokaust do strawienia}

Wydaje się, że kicz jest nieunikniony w filmie holokaustowym z co najmniej dwóch przyczyn. Po pierwsze, z powodu zasięgu przekazu: jako masowy i kreowany jako docelowo uniwersalny, skazany jest na zawartość kiczową. Po drugie zaś, estetyka kiczu daje możliwość nadania Holokaustowi znaczenia społecznie akceptowalnego (opowieść o tryumfie dobra nad złem), mieszczącego się w kulturowych normach i opowiedzianego znanymi sposobami.

Moles, pisząc o podstawowych wartościach kiczu, zaznacza, że jedną z najważniejszych jest „poczucie bezpieczeństwa wobec zdarzeń świata zewnętrznego, które stanowi pewną wartość idealną"10. Kicz nigdy nie jest częścią przekazu zagrażającego dobremu samopoczuciu odbiorcy, poczucie komfortu pozostaje tutaj jednym z nadrzędnych kryteriów. Natychmiast pojawia się paradoks. Skoro kino holokaustowe zdaje się poniekąd skazane na kicz, a jedną $\mathrm{z}$ podstawowych wartości kiczu jest dawanie odbiorcy sztuki poczucia bezpieczeństwa, to jak pogodzić te dwa tak skrajne zjawiska, jakie stanowią opowiadania na temat Zagłady $z$ jednej strony i potrzeba poczucia komfortu $\mathrm{z}$ drugiej?

Imre Kertész, pisząc o Holokauście dla masowego odbiorcy, nie pozostawia złudzeń co do niewiarygodności i nieprzystawalności tego zjawiska w stosunku do doświadczenia tych, którzy Zagładę przeżyli. „Ukształtował się obozowy konformizm - pisze Kertész - narodził się Holocaust sentymentalny, powstał kanon Holocaustu, tabu związane z Holocaustem i rytualny świat języka, powstał gotowy do spożycia produkt Holocaustu"11. Rzeczywiście, przekłamania historyczne obecne w filmach nie są najczęściej wielkimi oszustwami czy absolutnym nieposzanowaniem faktów, a nagromadzeniem drobiazgów, które zebrane razem mają dać obraz Holokaustu strawnego. Sam dramat pozostaje - ludzie krzyczą, są głodni, są zabijani, źli Niemcy strzelają do Żydów, ale wszystko to jest odrobinę nieprawdziwe. Getta rzadko kiedy są przeludnione, ludzie, mimo że głodni, dzielą się chlebem, no i zawsze mówią po angielsku z bliżej niezidentyfikowanym wschodnim akcentem. W obozach filmowych zachowana jest ludzka wspólnota cierpienia ofiar. Wśród Niemców zawsze znajdzie się jeden sprawiedliwy, a wśród więźniów obozów nie ma „muzułmanów”, nie kradnie się i nie kapuje. Można powiedzieć, że kiczem w rozumieniu przekłamania historii w kinie holokaustowym jest między innymi przywrócenie ofiarom ich ludzkiej godności, szlachetności. Z ofiarami, które wysiadają z bydlęcych wagonów uczesane, w niewymiętych, co najwyżej lekko przybrudzonych ubraniach, widz może spróbować się utożsamić. Tworzenie produktu holokaustopodobnego polega tu na przycięciu, skrojeniu świadectw dotyczących Zagłady do granic wytrzymałości widza. Tą - jak się zdaje, absolutnie nieprzekraczalną - granicą dla kina holokaustowego będzie zawsze poczucie bezpieczeństwa widza, czyli z jednej strony poczucie przełykalności historii, którą ogląda na ekra-

\footnotetext{
${ }^{10}$ A. Moles, op. cit., s. 101.

${ }^{11}$ I. Kertész, Język na wygnaniu, przeł. E. Sobolewska, Warszawa 2004, s. 123.
} 
nie, z drugiej - swego rodzaju rekompensata za wszystkie okropności, które gotów jest przyjąć w czasie trwania seansu. Jak ten komfort zapewnić?

Na ratunek przychodzi szczęśliwe zakończenie, czyli najprostsze dramaturgiczne zadośćuczynienie bohaterowi (a co za tym idzie, publiczności, która towarzyszy protagoniście w jego wędrówce), wynagrodzenie wszystkich trudności, przez które musi przejść w toku opowieści. Nie trzeba przytaczać rozlicznych zarzutów pod adresem filmów fabularnych o Holokauście, w których jak refren powtarza się argument, że z doświadczenia śmierci o nieznanych nigdy wcześniej rozmiarach i natężeniu kino holokaustowe tworzy historie o ocalonych, o sile ludzkiego ducha i o dobroci. Jak to ujął Tim Cole w swojej książce „Holokaust na sprzedaż”: „nie widzimy rzeczy takimi, »jakie były«. Widzimy rzeczy takimi, jakimi Hollywood sprawiło, aby były. Hollywood, począwszy od »Anny Frank« do »Oskara Schindlera«, oferuje »Holokaust «, który wciąż wierzy, że ludzie w głębi serca są dobrzy. Tworzy »Auschwitz« i »Holokaust«, nad którymi może przejść do porządku dziennego"12.

Jest jeszcze jeden ważny, jeśli nie najważniejszy element składowy kreowania na ekranie Zagłady „do wygodnego oglądania”, Zagłady niezagrażającej w żaden sposób poczuciu bezpieczeństwa publiczności. Polega on na ustawieniu samego prezentowanego na ekranie doświadczenia, nawet w wersji okrojonej, kiczowej, jako absolutnie i całkowicie zewnętrznego wobec widza. W największym skrócie: kino holokaustowe zawsze opowiada o tym, ,jak”, nigdy nie pyta, „dlaczego”.

\section{Opowieść o tym, jak, nie: dlaczego}

To, co kicz, jako swego rodzaju podejście do tematu, niesie ze sobą i co może stanowić prawdziwe zagrożenie, niekoniecznie tkwi w upraszczaniu historii Zagłady. „Nie są podawane powody - pisze Tim Cole - tego, co się dzieje. Filmy te nie tłumaczą mechanizmów, pokazują pewien przebieg [...] Nazizm to psychoza, nie jakakolwiek przyczynowość"13.

Faktycznie, wszystkie filmy dotyczące w jakikolwiek stopniu Zagłady opowiadają o tym, jak proces wymordowania Żydów wyglądał. Konstrukcje dramaturgiczne, o których pisałam wcześniej, skupiają się na tym, jak bohater ma się uratować lub jak może zostać uratowany. Żaden z filmów nie porusza kwestii, dlaczego akurat Żydzi byli zagazowywani w komorach, dlaczego właśnie Żydów zamykano w gettach, dlaczego to fabryki śmierci stały się głównym narzędziem ludobójstwa. Nikt nie szuka odpowiedzi na pytanie: „dlaczego?”. Kinematografia holokaustowa koncentruje się na pokazaniu, „jak” się toczyło ludobójstwo, nie „dlaczego” miało miejsce, czy choćby - jak do niego doszło.

Historyk będzie mógł prześledzić pewien proces, który doprowadził do obozów zagłady, pod warunkiem, że uzna, że Holokaust należy wpisać w pewien porządek historyczny, co przecież nie jest wcale oczywistym podejściem do Zagłady jako fak-

\footnotetext{
${ }^{12}$ T. Cole, Selling the Holocaust, New York 2000, s. 93.

${ }^{13}$ Ibidem, s. 83.
} 
tu historycznego. Na ten temat nadal toczą się dyskusje. Kino popularne natomiast konsekwentnie milczy na ten temat. To milczenie wydaje się znamienne. Można je zinterpretować jako brak zainteresowania odpowiedzią na pytanie: „dlaczego?” (co wydaje się o tyle mało prawdopodobne, że zbyt często powtarzane jest pytanie: „jak to się mogło stać?”), albo - i bardziej skłaniałabym się do takiej interpretacji - można owo milczenie potraktować jako przejaw całkowitej bezradności wobec tego, co próba odpowiedzi mogłaby przynieść.

Imre Kertész pisze: „Za kicz uważam też każdy utwór, którego autor nie jest w stanie - albo nie chce - zrozumieć związku między deformacją naszego zbiorowego oraz prywatnego życia i uznaniem Holocaustu za coś, co mogło mieć miejsce, a więc uznaniem, że Holocaust nie wynika z natury człowieka i nie należy go włączać w krąg ludzkich doświadczeń”14.

Brak choćby próby zadania pytania: „dlaczego?”, a więc zmuszenia widza do wejścia w tok rozumowania, które zbliżyłoby go do tych, którzy Zagładę obmyślili i przeprowadzili, jest jednym z najskuteczniejszych sposobów odrywania Holokaustu od jego namacalności, konkretności.

Drugim sposobem będzie skanalizowanie empatii widza zawsze po stronie tych, którzy przeżyli. Sam proces wyłączania Zagłady z doświadczenia ludzkiego, ale także pozbawianie Zagłady potencjału repetycji opisywał bardzo dokładnie Zygmunt Bauman w Nowoczesności i Zagładzie, tłumacząc, jak dalece tworzenie poczucia ontologicznej wyjątkowości Holokaustu jest niebezpieczne: usypia czujność, wykluczając ewentualność, że coś takiego może się powtórzyć.

W strukturze dramaturgicznej filmów fabularnych Holokaust jest zawsze przeszkodą, którą główny bohater pokonuje, a skoro pokonuje, to zostawia za sobą, czyli: niebezpieczeństwo zostaje zażegnane, historia jest skończona, zamknięta. Widz zostaje w swoim bezpiecznym kokonie, może wyjść z kina usatysfakcjonowany, z poczuciem jednorazowości wydarzenia przedstawionego na ekranie. Kiczem będzie tu danie widzowi komfortu, z którym spokojnie wraca do domu po skończonym seansie.

„Umieszczając morderstwo w klasycznych kategoriach pozytywnego bohatera i czarnego charakteru, Spielberg skutecznie wyłącza Holokaust z historii [...] Powieszenie Goetha skutecznie kończy zbrodnię, ponieważ uśmierca protagonistę zła. Wymowa jest prosta: nie ma takich ludzi jak Goeth, nie ma zbrodni”15. Tim Cole analizował ten mechanizm na przykładzie Listy Schindlera, ale zdaje się on obecny w każdym filmie holokaustowym.

To dążenie do nieporuszania kwestii mechanizmów Zagłady i ich zanurzenia we współczesności, o czym pisze Bauman, świadczyć może o panicznym lęku społecznym. Jesteśmy zdolni, jako publiczność, przełknąć wiele, byleby tylko nie konfrontowano nas z hipotezą, że Holokaust wcale nie jest zamkniętym rozdziałem, że jest nieustającą groźbą wiszącą nad społeczeństwem ponowoczesnym. Oglądanie

\footnotetext{
${ }^{14}$ I. Kertész, op. cit., s. 125.

${ }^{15}$ T. Cole, op. cit., s. 83.
} 
kolejnych hollywoodzkich produkcji trywializujących to zdarzenie, opływających kiczem, możemy śmiało traktować jako kojenie sumienia. Przecież nie uciekamy od tematu, tylko śmiało zmierzamy na seans, gdzie zostaniemy skonfrontowani z horrorem Zagłady, jednak mamy poczucie, że ta konfrontacja zakończy się miękkim lądowaniem, bo nikt nie spyta: „dlaczego?”, ani: „czy mógłbyś być sprawcą?”; będą pytać: „,o byś zrobił na miejscu ofiary?”, ,jak byś postąpił?”.

\section{Trywializacja versus hollywoodyzacja}

Niezwykle ciekawa jest pozornie drobna, jednak znamienna różnica w podejściu do tematu kiczu w odniesieniu do Holokaustu między Stanami Zjednoczonymi i Europą. To, co Imre Kertész nazywa subkulturą Holokaustu, Holokaustem sentymentalnym, czy wreszcie gotowym do spożycia produktem, a Elie Wiesel określił jako trywializację pamięci ${ }^{16}$, jest jednym i tym samym: zarzutem, że film przedstawia Holokaust za pomocą klisz, stereotypów, obrazów spłycających cierpienie ontologicznie niemożliwe do opisania czy wytłumaczenia. W Polsce takie zarzuty pod adresem kina holokaustowego wysuwali Tadeusz Sobolewski czy Agnieszka Holland ${ }^{17}$.

W pojęciach „trywializacja” czy „banalizacja” tkwi zarzut, że filmy fabularne udają coś, czym nie są i być nie mogą. Upraszczają, ułatwiają, wychodzą w stronę widza w sposób haniebny, bo urągający ofiarom Holokaustu, ich pamięci, ich cierpieniu. Czy tak rzeczywiście jest i czy taki argument jest zasadny, to wydaje się kwestią indywidualnego odbioru, lecz jedno pozostaje pewne: w Europie, w tym także w Polsce, według krytyków kicz filmów holokaustowych tkwi w ich nieprzystawalności do historii, w ich prostej, żeby nie powiedzieć prostackiej, konstrukcji.

Takie rozumowanie bierze za punkt wyjścia fakt historyczny oraz konkretne, choć często niepoznane ofiary Zagłady. Można zatem uznać, że oczekiwania wobec takiego typu kina mogą być dwojakie: albo kino popularne powinno pomijać temat Zagłady, bo nie jest w stanie przekazać tej historii w sposób wiarygodny, albo powinno stworzyć wewnątrz siebie nowy język, nowy sposób na pokazanie Holokaustu. Zupełnie inaczej rzecz ma się w Stanach Zjednoczonych, gdzie to samo zjawisko określane jest całkowicie innymi terminami: „amerykanizacją” czy też „hollywoodyzacją" Holokaustu.

Zarówno Peter Novick, piszący o włączeniu Holokaustu w świadomość nie tylko amerykańskich Żydów, ale wszystkich Amerykanów, jak i Tim Cole, opisujący dostosowywanie Holokaustu do wrażliwości i możliwości percepcyjnych Amerykanów, mówią właściwie o tym samym zjawisku, które Kertész czy Wiesel określają

${ }^{16}$ E. Wiesel, Art and the Holocaust: Trivializing memory, „New York Times”, 11 VI 1989.

${ }^{17}$ T. Sobolewski, Pianista, „Kino” 2002, nr 7/8. Filmowe zwierciadła Holokaustu („Wokół Pianisty Romana Polańskiego”). Z Agnieszką Holland rozmawia Jan Strzałka, „Tygodnik Powszechny" 2003, nr 13, s. 12. 
mianem trywializacji. I Novick, i Cole wychodzą jednak z odmiennego założenia i rozumieją ten proces nieco inaczej.

„Amerykanizacja” Holokaustu jest nie tyle spłycaniem wydarzenia historycznego, ile dostosowywaniem języka mówienia o tym wydarzeniu do odbiorcy, w tym przypadku społeczeństwa amerykańskiego. Punktem wyjścia dla takiego rozumowania będzie odbiorca komunikatu, a nie wydarzenie historyczne, które ma być tego komunikatu treścią. Kicz będzie w takim razie służył jako specyficzny rodzaj tłumacza zdarzenia historycznego, które przez to, że jest obce, nieprzynależne bezpośrednio do continuum historycznego narodu amerykańskiego, musi zostać przeformułowane tak, aby społeczeństwo czy precyzyjniej mówiąc: pamięć społeczna mogła ten fakt przyswoić i wchłonąć. Do tego procesu tłumaczenia wydarzenia na język zrozumiały dla wszystkich jest wykorzystana owa symboliczna wartość kiczu, jego uniwersalność i niezwykła elastyczność.

Przesunięcie punktu ciężkości z faktu historycznego na społeczeństwo, które ma ten fakt poznać i przyswoić, nie oznacza, że badacze amerykańscy nie widzą zagrożenia, jakie proces hollywoodyzacji Zagłady za sobą pociąga. „Od momentu powstania mitu Holokaustu - pisze Cole - nieustającym zagrożeniem jest fakt, że »mit» stał się "prawdziwszy« niż »rzeczywistość« historyczna. Pod koniec XX w. wydaje się oczywiste, że mity stały się bardziej realne od historii”18.

\section{Typologia kiczów}

Mity mają swoje bardzo konkretne wzory narracyjne i kino holokaustowe czerpie z tych struktur pełnymi garściami. Warto prześledzić przynajmniej kilka typów kiczu, które kino holokaustowe oferuje w niezwykłej obfitości. Wszystkie one nawiązują do najbardziej podstawowych mitów naszej kultury.

Trzeba zaznaczyć, że poniższa typologia jest raczej propozycją niż zamkniętym konstruktem. Film taki jak Lista Schindlera będzie zawierał zarówno elementy kiczu chrześcijańskiego, syjonistycznego, jak i patosu. Życie jest piękne będzie kiczem zarówno chrześcijańskim, jak i magicznego końca. Granice między poszczególnymi typami są zapewne płynne, jednak wydaje mi się, że konkretne typy kiczu wykorzystują pewne wzory opowieści, mitów, baśni, które są obecne w kulturze od początku.

\section{Kicz patosu}

Są to filmy najczęściej poświęcone tym, którzy przeżyli. Zazwyczaj opowiadają one historię heroicznych czynów i wyborów orbitujących wokół ratowania Żydów. Stąd bohaterami tego typu filmów przeważnie nie są Żydzi, tylko ludzie ratujący Żydów lub pomagający im w ukrywaniu się. Lista Schindlera, Musimy sobie poma-

${ }^{18}$ T. Cole, op. cit., s. 75-76. 
gać, Dzieci Ireny Sendlerowej czy Daleko od okna Jana Jakuba Kolskiego z 2000 r. to tylko wybrane tytuły.

Początkowo bohater przeżywa dylemat moralny, czy ma ratować Żydów, czy chronić siebie. Po podjęciu decyzji o ratowaniu, co jest najczęściej zawiązaniem akcji, nadchodzi okres ukrywania/ratowania. Nagrodą, jaka czeka na bohatera, jest zachowanie ludzkiej godności, a także (o czym widz dowiaduje się najczęściej w napisach na końcu filmu) medal Sprawiedliwego Wśród Narodów Świata. Jeżeli akcja dzieje się w obozie, to zazwyczaj przetwarza historię łagrów w opowieść o wyzwoleniu.

Filmy tego gatunku utrzymane są zazwyczaj w tonie absolutnej powagi. Kicz polega tam na mozolnym, jednotorowym budowaniu świata przedstawionego w taki sposób, żeby widz nie mógł mieć nawet przez chwilę wątpliwości, że próba, przez którą przechodzi bohater, jest niebezpieczna i groźna. Archetypem tego typu filmów jest Lista Schindlera, gdzie patos sięga zenitu w scenie ucieczki Schindlera z obozu tuż przed wkroczeniem wojsk radzieckich. Schindler, pochylając się nad samochodem, wyrzuca sobie, że mógł uratować więcej Żydów. Konsekwentnie budowany heroizm postaci Schindlera jest wykorzystany do granic możliwości, nie dając widzowi żadnego innego wyboru niż odczuwanie kiczowego wzruszenia.

Filmy o Zagładzie, które kończą się wraz z końcem wojny i uratowaniem tych, którzy skazani byli na pewną śmierć, mają wymiar przede wszystkim moralizatorski. Kicz - czyli w pojęciu Brocha: kłamstwo - kryje się w tym, że, jak to ujął Stanley Kubrick, Holokaust jest o 6 milionach, które zginęły, Lista Schindlera o 1200, którzy przeżyli. Pułapką tych filmów jest sam układ dramaturgiczny. Film ma zostawić widza z poczuciem nadziei, główny bohater czy bohaterowie nie mogą zatem zginąć. Skoro nie mogą zginąć, trzeba za bohaterów wziąć tych, co przeżyli. Tych jest znikomy procent $\mathrm{w}$ stosunku do zagazowanych. Paradoks nie do przełamania. Jednak warto zadać sobie pytanie: jaką konkretnie potrzebę widowni te filmy zaspokajają?

Wydaje się, że jest to potrzeba postawienia jakiegokolwiek znaku plusa przy Holokauście, takiego przetworzenia tego wydarzenia historycznego, aby stało się czymś pozytywnym, żeby nie było negacją człowieczeństwa i kultury, tylko opowieścią o ratowaniu godności, życia. Z punktu widzenia analizy struktury filmowej jest to decyzja w pełni uzasadniona: dobry film to taki, w którym główny bohater przechodzi przemianę, skutkiem której na końcu znajduje się $\mathrm{w}$ innym punkcie życiowym, jest innym człowiekiem. A jeśli takie uniwersalne nadanie znaczenia nie wystarczy? Wtedy wpisuje się Zagładę w mit państwowotwórczy.

\section{Kicz syjonistyczny}

Filmy kiczowe syjonistyczne bardzo łatwo rozpoznać. Bohaterowie, którym $\mathrm{z}$ większym lub mniejszych zaangażowaniem kibicowaliśmy przez cały film, w finałowej sekwencji zostają zastapieni „oryginałami”, czyli ludźmi, których historie były pierwowzorami scenariusza i których kopie oglądaliśmy na ekranie. Najczęściej są pokazani, jak wspólnie kroczą w stronę kamery i - co za tym idzie - widza. 
Jeżeli nie można pokazać prawdziwych ludzi, co z racji upływającego czasu jest coraz trudniejsze, pokazuje się przynajmniej zdjęcia. Celem takiego zabiegu nie jest jedynie uwiarygodnienie opowiedzianej historii, ale też pokazanie założycieli nowego Izraela, ludzi, którzy dzięki temu, że przeżyli, stali się ojcami nowego narodu.

Oczywiście znów Lista Schindlera, gdzie w końcowej sekwencji Żydzi Schindlera maszerują pod rękę w takt hebrajskiej piosenki, będzie tu archetypicznym przykładem wykorzystania tego typu zabiegu, ale nie jest to najciekawszy film o wymowie syjonistycznej. Dużo bardziej interesujący jest niedawny film Opór Edwarda Zwicka $^{19}$ z 2008 r., oparty na historii braci Bielskich. Obsadzenie w roli jednego z nich Daniela Craiga, kojarzonego głównie z rolą Jamesa Bonda, to nadanie nowej jakości filmom o Holokauście.

W Liście Schindlera Żydzi byli bierną masą, o którą musiał walczyć dobry Niemiec. W Oporze Żydzi są zostawieni sami sobie i walczą sami o siebie. W końcowej sekwencji to żydowska partyzantka stacza zwycięską bitwę z Niemcami. Żydzi sami przechodzą, związani paskami i sznurówkami, przez Morze Czerwone Europy Wschodniej, czyli bagna, sami tworzą minipaństwo w lesie, sami siebie ratuja pod przywództwem niebieskookiego, blondwłosego Daniela Craiga.

Kicz, czy nawet momentami śmieszność tego filmu nie wynika z ogólnej chęci przetworzenia Holokaustu w historię o ratowaniu ludzkiej godności. Kicz syjonistyczny polega na natrętnym i wtórnym wykorzystaniu symboli w celach uzasadniających istnienie realnej konstrukcji politycznej. Neurotyczne, jak by je określił Broch, czyli całkowicie nierealne środki, ahistoryczne podejście, nieudokumentowane postaci, przekłamania widoczne dla każdego, kto choć w znikomym stopniu interesuje się tematem Zagłady, są użyte z pełną powagą do nadania Holokaustowi znaczenia początku prawdziwego, realnego, fizycznego państwa, jakim jest Izrael.

Kicz objawia się w tego typu filmach w momentach nadawania symboliki wspólnotowej działaniom postaci (przejście przez bagna niczym przez Morze Czerwone). Jeśli jednak nie opowie się Holokaustu jako historii o ratowaniu albo tworzeniu nowego Izraela, bardzo często kino holokaustowe wybiera jeszcze jedną dostępną formułę, czyli opowieści o poświęceniu.

\section{Kicz chrześcijański}

Opowieści o człowieku czy ludziach oddających życie, aby inni mogli żyć, czerpią wzory niemal całkowicie z kultury chrześcijańskiej. Takie struktury dramaturgiczne są bardzo częste w kinie holokaustowym, dość przytoczyć Życie jest piękne Roberta Benigniego z 1997, o dwa lata młodszy film Jakub kłamca, czy dużo nowszy i przez to mniej opisany film Chłopiec w pasiastej piżamie.

Wszystkie wymienione filmy łączy wspólne rozwiązanie dramaturgiczne. Jedna z głównych postaci umiera w imię ratowania idei (fikcyjne radio w przypadku Jaku-

${ }^{19}$ Twórca takich filmów jak epicki Ostatni samuraj czy melodramat Wichry namiętności. 
ba kłamcy, gra w obóz w przypadku Życie jest piękne), która daje nadzieje i chroni psyche pozostałych postaci przed horrorem sytuacji, w jakiej się znaleźli. Tak jak Jezus umarł na krzyżu, dając ludzkości nadzieję na wieczne odkupienie, tak bohaterowie tych filmów biorą na siebie cały ciężar Zagłady (czytaj: świadomość jej okropności), aby inni byli nią zarażeni w mniejszym stopniu.

W przypadku Chłopca w pasiastej piżamie postacią poświęcającą się jest niemieckie dziecko - Bruno - które wchodzi do obozu, aby pomóc żydowskiemu rówieśnikowi odnaleźć ojca. Bruno ginie w komorze gazowej. Rodzice, w tym ojciec, który jest komendantem obozu, nie zdążają go uratować. Jest to jeden z tych filmów, w których katalog wszystkich nieprawdopodobieństw historycznych może przyprawić o ból głowy. Jeśli natomiast skoncentrujemy się na symbolice niektórych scen, odnajdziemy w nich odniesienia niemal biblijne.

W jednej z sekwencji, już po tym, jak Bruno zaprzyjaźnia się przez drut kolczasty z żydowskim rówieśnikiem, widzimy, jak dziecko-więzień zostało przyprowadzone do domu komendanta, by wycierać kieliszki przed przyjęciem. Bruno zachęca chłopca, by poczęstował się ciastkami, które leżą na tacy, gdy jednak ten zostaje przyłapany na jedzeniu przez oficera SS i tłumaczy, że otrzymał pozwolenie, Bruno wypiera się dwukrotnie znajomości z żydowskim dzieckiem. Wejście do obozu ma być dla Brunona odkupieniem jego, piotrowego skądinąd, grzechu zaparcia się. Bruno ginie za swoje winy, ale też - zdaje się - za winy całego społeczeństwa zachodniego, które w swoim czasie wyparło się, zamknęło oczy na tragedię Żydów. Stąd taka śmierć na ekranie może być dla widza nie tylko akceptowalna, ale wręcz pożądana.

W tym przypadku kicz będzie oznaczał nachalność jednotorowego rozumienia i nadawanie bardzo konkretnego, szlachetnego znaczenia śmierci. Religia chrześcijańska w przeciwieństwie do żydowskiej nadała cierpieniu i śmierci znaczenie pozytywne, uszlachetniające, stąd nic dziwnego, że w kinie holokaustowym często sięga się po symbolikę chrześcijańską. Cokolwiek może nadać śmierci niewinnych ludzi sens i znaczenie, jest tu pożądane. Dlaczego? Bo widz kina popularnego zdaje się absolutnie nieprzygotowany (tu pamiętajmy o zasadzie nienaruszalności poczucia bezpieczeństwa) na fakt, że postać, w którą „zainwestował” emocjonalnie, miałaby umrzeć na marne. To z kolei prowadzi nas do ostatniego już, niezwykle silnie obecnego wzorca kiczu w kinie holokaustowym.

\section{Kicz magicznego końca}

Można wymienić całą litanię filmów o Zagładzie, które kończą się w podobny sposób. Bohaterom nie udaje się ukryć przed Niemcami czy wydostać z getta/obozu, czeka ich śmierć. Już towarzysząc postaci w bydlęcym wagonie, który zmierza do obozu, widz wie, jaki będzie koniec. Tak kończy się Jakub kłamca czy Korczak. Inne filmy posuwają się dalej. Kamera towarzyszy postaci do komory gazowej (Chłopiec w pasiastej piżamie, Arytmetyka diabła Donny Deitch z 1999 r.). Niewiele jednak filmów wytrzymuje tragiczne zakończenie historii. Jedynym znanym mi przykładem jest Szara strefa, gdzie wszyscy bohaterowie (członkowie Sonderkom- 
manda, które wszczęło powstanie w Auschwitz, i odratowana przez nich z komory gazowej dziewczynka) giną i zostaje to pokazane.

W wielu filmach holokaustowych, aby zniwelować czy osłodzić widzowi tragizm śmierci bohatera, wykorzystany jest ten sam chwyt dramaturgiczny - sekwencja marzenia, myślenia życzeniowego, które odzwierciedla nierealne (neurotyczne, jak by powiedział Broch) marzenia widza. Zostaje tu zawiązana pewnego rodzaju umowa z widzem. Wszyscy wiedzą, jak ta historia naprawdę się kończy, jednak na ekranie pokazane jest marzenie, całkowite zaprzeczenie tego, co według zasad prawdopodobieństwa powinno się zdarzyć. Na tym polega siła i magia kina, że widz może i chce zostać oszukany, jeśli na szali leżą jego emocje, jego dobre samopoczucie.

W Jakubie kłamcy koniec to, co prawda, śmierć tytułowego bohatera, ale w jego komentarzu zza grobu pojawia się hipoteza, że może wcale Żydzi z getta nie pojechali do obozów. Przedstawiona zostaje alternatywna, marzeniowa sekwencja, w której rosyjskie wojska odbijają transport, a dziewczynka, którą tytułowy Jakub się zajmował, widzi amerykański jazz-band występujący na czołgu.

Andrzej Wajda w Korczaku z 1990 r. dokonuje takiej samej ucieczki w marzenie, odczepiając wagon z wychowawcą i sierotami, i dając im możliwość wybiegnięcia na rozświetloną łąkę. W telewizyjnej Arytmetyce diabła cały film, którego część wojenna kończy się zamknięciem głównej bohaterki w komorze gazowej wraz z innym kobietami, okazuje się snem współczesnej Żydówki, która nie chce zaakceptować swojego żydowskiego pochodzenia, nie uczestnicząc w rodzinnej uroczystości. Tuż przed momentem wrzucenia cyklonu B do komory bohaterka grana przez Kirsten Dunst budzi się z niespokojnego snu.

Nawet w filmie Życie jest piękne śmierć ojca zostaje zadośćuczyniona synowi i osłodzona szczęśliwym zbiegiem okoliczności. Gra, w którą grał z tatą w obozie, dobiega oczekiwanego końca: malec „dostaje” czołg, a przejażdżkę wieńczy odnalezienie matki.

Na tym tle film Szara strefa wyróżnia się na kilku płaszczyznach. Przede wszystkim jest to chyba jedyny film, który ponosi ciężar zakończenia. Bohaterowie, którzy odratowali niedogazowaną dziewczynkę, giną wraz z nią. Ostatnia sekwencja pokazuje na zwolnionych obrotach nową brygadę Sonderkommando pracującą przy piecach krematoryjnych. Spoza kamery dochodzi poetycki komentarz wypowiadany głosem zastrzelonej dziewczynki, opisujący podróż prochów z krematoriów.

Kicz tych onirycznych zakończeń leży nie tylko w ich niemożliwości czy - często - sennej estetyce, ale także w zapewnianiu widzowi poczucia bezpieczeństwa, choćby całkowicie pozornego, ulgi, że przecież wszystko dobrze się ułożyło (przynajmniej na ekranie). Komfort widza jest wyszarpywany kosztem prawdopodobieństwa, wynikającego już nie tyle z prawdy historycznej, ile z zasad funkcjonowania świata przedstawionego. Filmy holokaustowe poza nieznacznymi wyjątkami zdają się niezwykle konsekwentnie odmawiać pokazania prawdziwego i najstraszniejszego oblicza Zagłady, jakim jest masowa śmierć. W sali kinowej chyba nie ma dla niej miejsca. 


\section{Katharsis kampu poza granicą kiczu}

Być może nie wypada o tym pisać, ale zdarza mi się śmiać na filmach holokaustowych. Kiedy oglądam Daniela Craiga na białym rumaku galopującego po lesie w Oporze, czy kiedy widzę Brunona, bohatera Chłopca w pasiastej piżamie, przebierającego się w obozowe ubrania i przekopującego się na teren obozu, nie mogę powstrzymać śmiechu. Śmiech ten jest wywołany głównie świadomością zabiegów, którym jako widz jestem poddawana. Z tego doświadczenia rodzą się dwa pytania: co się dzieje z kiczem, kiedy odbiorca ma jego całkowitą świadomość? I drugie: czy twórcy filmów holokaustowych wykorzystują świadomie estetykę kiczu, a jeśli tak, to do czego?

Wydaje mi się, że można podać co najmniej kilka przykładów filmów na różne sposoby posługujących się kiczem jako świadomym środkiem artystycznym. Będą to między innymi: Pianista Romana Polańskiego (głównie sztuczność scenografii zniszczonego miasta), Życie jest piękne Roberta Benigniego, Pociag życia i oczywiście Bękarty wojny Quentina Tarantino.

Wszystkie te filmy zdają się wykorzystywać kicz jako swego rodzaju element gry z widzem, płaszczyznę porozumienia. Płaszczyzna ta może dotyczyć umowności opowiadanej historii (Życie jest piękne), pokazania niemożności znalezienia niekiczowego języka na opisanie Zagłady (Pianista) czy też szaleńczej bajkowości, która zostaje przerwana brutalną, ironiczną wymową ostatniej, realistycznej, sceny (Pociag życia).

Tak czy inaczej, filmy te starają się przekroczyć granicę kiczu, czyli granicę powtarzalności obrazów, poczucia bezpieczeństwa widza, neurotyczności przedstawienia, dając widzowi sygnały, że to, co ogląda, i tak nie jest prawdziwe, jest tylko przykrywką dla tego, czego pokazać się nie da. Takie zabiegi formalne i dramaturgiczne nie byłyby z kolei możliwe bez szeregu filmów, które nieświadomie ugruntowały pewne, opisane powyżej, chwyty kiczowe. Skoro jednak język kiczu filmów holokaustowych został ugruntowany, to można go wykorzystać w sposób świadomy, tym samym nadając kolejnym filmom nową jakość artystyczną. Najlepszym przykładem takiego wykorzystania kiczu są Bękarty wojny Quentina Tarantino.

Susan Sontag w 1964 r. napisała esej Notatki o kampie, w którym starała się uchwycić istotę specyficznej estetyki przesady, określając ją jako jedną z wielkich wrażliwości twórczych (zaraz po moralistycznej wrażliwości powagi i ekstremalnej wrażliwości fragmentu). „Trzecią z wielkich wrażliwości twórczych jest właśnie kamp: chybiona powaga, teatralizacja doświadczenia. Kamp odrzuca zarówno harmonię powagi tradycyjnej, jak i ryzyko pełnego utożsamienia z ekstremalnymi stanami odczuwania” ${ }^{20}$. Z kolei Umberto Eco pisze: „Kamp to również, choć nie zawsze, doświadczenie kiczu przez kogoś, kto wie, że tym, co widzi, jest kicz”21.

${ }^{20}$ S. Sontag, Notatki o kampie, przeł. W. Wertenstein, „Literatura na Świecie”, 1979, nr 9, s. 319.

${ }^{21}$ U. Eco, Historia brzydoty, przekł. zbiorowy, Poznań 2007, s. 411. 
Wydaje się, że nie ma lepszego opisu estetyki Bękartów wojny niż dwa cytaty zamieszczone powyżej. Wycinanie swastyki na czołach nazistów, muzyka prosto z westernów, rzeź, którą Żydzi w płonącym kinie urządzają niemieckim dygnitarzom - niemal każda scena filmu Tarantino przesiąknięta jest świadomą przesadą, nadgrywaniem środkami filmowymi, zabawą z konwencją. Nie będzie chyba przesadą określenie Bękartów wojny już nie jako filmu do cna kiczowego, ale właśnie kampowego, gdzie wszystko jest „konsekwentnie estetycznym przeżywaniem świata. Wyraża zwycięstwo »stylu« nad »treścią«, »estetyki« nad »moralnością«, ironii nad powaga"22.

Estetyka absolutnej zabawy, chronicznej umowności, umożliwiła danie widzom tego, czego cały świat zachodni pragnął - Hitler został zabity, zmasakrowany, spalony. Bękarty wojny tylko poprzez kampowość mogły zrealizować marzenie mieszczące się poza jakimkolwiek prawdopodobieństwem, jakimkolwiek wypaczeniem historycznym, dając publiczności poczucie satysfakcji, jaką można osiągnąć widząc - choćby tylko na ekranie - jak zostaje zrealizowane najskrytsze marzenie. Kampowa katharsis, wyimaginowana zemsta wydaje się jedynym w pełni dostępnym, emocjonalnie osiągalnym oczyszczeniem, jakie ma do zaoferowania kino holokaustowe. Kiedy już wiadomo, że kicz jest kiczem, jedyne, co można zrobić, to potraktować go jako przepustkę do prawdziwego puszczenia wodzy wyobraźni, co Tarantino zrobił wbrew zasadom minimalnego choćby prawdopodobieństwa historycznego. Kiczem zanegował historię, zmienił jej bieg. Efektem jest totalna rzeź, w której publiczność uczestniczy jak zahipnotyzowana.

\section{To tylko kicz}

Starałam się pokazać, że kicz w równym stopniu zasługuje na krytykę, co na uwagę, odgrywa bowiem niezwykle istotną rolę w tworzeniu świadomości społecznej dotyczącej Zagłady, spełniając tym samym funkcję kulturotwórczą. Różne filmy holokaustowe stosują różne metody kierowania emocjami widza, w różnym stopniu pozwalają kiczowi rozprzestrzeniać się w strukturze dramaturgicznej i formalnej obrazu, co nie zmienia faktu, że niewiele jest wśród nich takich, które nie zawierałyby w sobie elementów kiczu w ogóle.

Kicz zdaje się w przypadku kina holokaustowego nieunikniony. Czy będzie to kicz podsycanej za wszelką cenę powagi, czy kicz nadawania Holokaustowi znaczenia państwowotwórczego czy chrześcijańskiego - pozostaje faktem, że widzowie potrafią znieść wiele, żeby tylko nie czuć emocjonalnego zawodu i rozczarowania. Niektóre filmy wchodzą w grę z kiczem, łamiąc tym samym wszelkie zasady przyzwoitości i historycznej adekwatności.

Pozostaje jeszcze kwestia nieustającego zainteresowania publiczności tematem Zagłady, co samo w sobie jest zastanawiające. Dlaczego ludzie chodzą na filmy holokaustowe? Czy nie mają dość tych samych, powtarzających się w kółko obra-

${ }^{22}$ S. Sontag, op. cit., s. 319. 
zów pasiaków, wagonów, psów, esesmanów w wyglancowanych oficerkach? Może w społeczeństwie nastawionym w stu procentach na wygodę jedyną formą pamiętania takiej tragedii jak Holokaust jest seans filmowy, gdzie widz wie, że nie zostanie zraniony, co najwyżej draśnięty brutalnymi obrazami, gdzie Zagłada jest przykrojona do bezpiecznych rozmiarów i gdzie zazwyczaj bohaterom udaje się przeżyć? Jeśli tak, kicz w kinie holokaustowym jest jak zastrzyk przeciwbólowy - działa doraźnie, otumania, ale pomaga znieść uraz.

\title{
Słowa kluczowe
}

kino o holokauście, kicz, kultura popularna, happy-end, kamp

\begin{abstract}
The text deals with popular cinema that touches upon the subject matter of the Holocaust and the kitsch esthetics which is either intentionally or unintentionally often adopted in such films. The main questions to which the author seeks the answer is: why do we need kitsch to create stories about the Holocaust? The author defines the term Holocaust film and then suggests a typology of Holocaust films with respect to cultural references and narrative archetypes of stories which are often used in such films. Different types of Holocaust films are presented: Christian kitsch, Zionist kitsch, pathos kitsch and magic ending kitsch. The kitsch is treated here not as a critical category but as an esthetics having its own power and positive meaning. Nevertheless, the text refers to the ongoing debate about the subject matter of kitsch its one-sided perception, on the one hand, as esthetics destroying art and sensitivity, and on the other, as a necessary and creative element of culture.
\end{abstract}

\section{Key words}

Holocaust film, kitsch, popular culture, happy ending, camp 